\title{
Ролята на биофилмите в медицината и заболяванията на ушите, носа и гърлото
}

The Role of Biofilms in Medicine and Ear-nose and throat diseases

\author{
С. Върбанова, Д. Попова, М. Мелничаров \\ Медицинска академия - София \\ УМБАЛ "Царица Йоанна" - София, Катедра УНГ-болести \\ S. Varbanova, D. Popova, M. Melnicharov \\ Medical Academy - Sofia \\ Multi-profile University Hospital for Active Treatment "Queen Joanna" - Sofia \\ ENT Department
}

Summary

Introduction: The aim of this article is to present the acquired knowledge of biofilms in nature and the human organism.

Materials and Methods: Studying the nature, development and spread of biofilms, as well as their relation to chronic infections, especially in the presence of various kinds of implants, leads to a brand new concept of their treatment and prevention. The chronic infections of the ear, nose and throat rouse special interest and attention in the light of biofilm knowledge.

Discussion: These cavities, active in the initial contact of the human organism with surrounding nature are subject to different surgical interventions using various human matter (implants) such as: the placing of drainage tubes in the tympanic membrane, implants in the middle and inner ear, speech prothesis, endo-thracheal tubes and dilutors.

\section{Резюме}

Въведение: Целта на тази статия с да се представят натрупаните знания за биофилмите в природата и човешкия организъм.

Материал и методи: Изучаването на същността, развитието и разпространението на биофилмите, както и отношението им към хроничните възпаления, особено при наличието на различни видове импланти, води да нови конщепции за лечението и превенцията им. Хронични възпаления на ушите, носа и гърлото прсдизвикват особен интерес и внимание в светлината на знанията за биофилмите.

Дискусия: Това са кухинни органи, участващи в първите контакти на човешкия организъм с околната среда, и са обект на различни хирургически интервсншии с използване на чужди материи (импланти) като: поставянето на дренажни тръбички на тыпанчевата мембрана, протези в средното и вътрешното ухо, говорни протези, трахеални канюли, тръби и дилататори.

\section{Увод}

Биофилмите в медицинската практика са особено важни, защото са открити при повечето от микробните инфекции при човека. Поведението при хроничните инфекции, начините и методите за окончателното им решаване се свързва все повече с биофилмите в природата и в човешкия организъм. Особено ценни в този случай са проучванията, експериментите и наблюденията върху този природен феномен, какъвто са биофилмите и прилагането на натрупаните знания при лечението и поведението при персистиращите и т. нар. „нелечими“ хронични възпаления и състояния.

\section{Определение}

Биофилмите са агрегационен комплекс от микроорганизми и адхезивен матрикс. Те се характеризират от повърхностно прикрепените, структурно различни и генетично разнообразни съвкупности микроорганизми с общи взаимодействия, разположени в извънклетъчен матрикс от полимерни субстанции.

Друго описание определя биофилмите като многоклетъчни бактериални общности, успешно формирани и преживяващи благодарение на генно коопериране и взаимодействие помежду им.

Едноклетъчните организми имат най-общо два различни модела на поведение. Първият е известен като свободно плуване или планктон, в образуването на който единичните клетки се носят или движат самос- 
тоятелно в течна среда. Вторият е свързано състояние в общност, при което клетките са близко наредени и здраво прикрепени една към друга. Промени в поведението им се предизвикват от различни фактори, включително обмен на генна информация, както и други механизми. Когато клетката се включва в модела, тя претърпява фенотипна промяна на поведение, регулирано от различни гени.

\section{Образуване}

Проучени са 5 фази на развитието на биофилмите: начално прилепване, променливо прилепване, узряване, второ узряване и разпространение.

Формирането на биофилма започва със закрепването на свободно движещите се микроорганизми към повърхността (биологична или небиологична). Тези първи колонизации се придържат на повърхността за седмица, което зависи от силите на van der Waals. Ако те не се отделят веднага от повърхността, могат да се закрепят здраво и трайно чрез структурите за клетъчни спойки (каквито са клетъчните реснички).

Началните колонизации улесняват прикрепването и на други клетки чрез адхезии, с което започва образуването на matrix (сърцевината), който осигурява целостта на биофилма. Някои разновидности нямат възможността да се прилепват сами към матрикса, но имат способността да се обединят с образувани преди това колонии. По време на тази колонизация клетките могат да взаимодействат помежду си. Крайната фаза от формирането на биофилма е развитието му, когато той е факт и се променя само по форма и големина. Предимство от съжителстването на тази съвкупност е резистентността към отмиване и действието на антибиотици, тъй като пльтният екстрацелуларен matrix и външният слой предпазват клетките във вътрешността на общността.

Такова развитие на биофилма позволява на клетките му да станат антибиотично резистентни. В някои случаи антибиотичната резистентност нараства до 1000 пъти.

\section{Характеристики}

Обикновено биофилмите се откриват като солидни субстанции, потопени в някакъв течен разтвор, въпреки че те могат да се формират като плуващи матрици, покрития върху течна повърхност или върху други повърхности при много влажен климат. Те могат да съдържат различни микроорганизми като бактерии, гъбички, archaea, protozoa, всяка група от които изпьлнява специфична метаболитна функция. При определени условия някои микроорганизми могат да образуват моноспецифични филми.

Биофилмът се държи и протектира от matrix, отделящ полимерни съставки, наречени EPS-извънклетъчни полимерни субстанции или външни полизахариди. Този matrix протектира клетките вътре в биофилма и обезпечава възможността за комуникация между тях чрез биохимични сигнали. Установено е, че някои биофилми могат да съдържат водни канали, което помага за разпределението на хранителните и сигнални молекули. Matrix е достатъчно здрав и при някои състояния биофилмът като че ли се „вкаменява“, което се свързва с многократното увеличаване на антибиотичната резистентност.

Биофилмите са навсякъде. Прието е, че медицински значимите микробни биофилми са идентични с тези от всяка друга екосистема. Почти всички микроорганизми, не само бактериите и archaea, притежават механизми и възможности за закрепване към повърхността и помежду си. Биофилми могат да бъдат открити по скалите, морските и речни камъчета, по дъното на потоци и реки, а често се образуват и по повърхността на застояли водни басейни. Те са важна част от хранителните вериги в реките и потоците и се консумират от водните безгръбначни, с които се хранят много риби. Биофилми растат в топлите басейни в Националния парк Yellowstone, където достигат до 0,5 м и върху полегатите склонове в Антарктида.

В индустрията биофилмите могат да се развият върху вътрешностите на тръбопроводи, което причинява стеснението и корозирането им. Те могат да помогнат при елиминирането на петрола от замърсявания на океаните и моретата. Това става благодарение на активността на бактериални общности, притежаващи специални разграждащи ензими, наречени хидрокарбонкластични бактерии.

Изследователи установяват биофилми навсякъде в човешкото тяло, в области, покрити с влажни лигавици, с предпоставки и възможности за развитието им. Бактериалните биофилми имат голям потенциал за предизвикването на заболявания, който не бива да се пренебрегва. За кратко време изследванията доказват, че наличието на вътрешни биофилми е причината за различни хронични инфекции и заболявания, като броят им нараства непрекьснато.

Биофилмите са важни за медицинската практика, защото са причина за около $80 \%$ от микробните заболявания на човека. Те могат да се открият в меките тъкани на устата, зъбите и зъбните имплантати, гастроинтестиналния тракт, уро-гениталната 
система, въздушната система на белия дроб, протези на пикочната система, очи и протезите им, перитонеални мембрани и диализни и други видове катетри, имплантати на сърцето като пейсмейкъри, клапни протези, синтетични съдови платна и протези, вътрешни фиксиращи устройства, кожни шевове, трахеални и вентилационни тръби, имплантати в средното ухо, кохлеята и ствола и ставни протези.

Микроорганизмите стават все по-резистентни към антимикробните агенти, което затруднява имунната система на макроорганизма при осигуряването на съответния адекватен отговор.

Биофилмите са трудни за лечение с антимикробни средства, които могат да бъдат инактивирани и не преминават във вътрешността на биофилма. Бактериите в биофилма увеличават до 1000 пъти резистентността си към антимикробните средства, выпреки че някои от тях са показали чувствителност в състояние на планктон. В биофилмите се увеличава възможността за генен трансфер между бактериите. Това е важно, тъй като бактериалната резистентност към антимикроби и пестициди може да се предаде чрез гени за резистентност успешно и на съседните бактерии. Този генен трансфер може да превърне един авирулентен съседен микроорганизъм в много вирулентен патоген. Биофилмът увеличава и възможността на бактериите да комуницират една с друга. Развитието им е съвсем различно в средата на биофилма, когато нутритиентите и кислородът са ограничени и голяма част от продукцията на съседните клетки е токсична. Бактерии, закрепени вътре в биофилма, са резистентни и към имунологичните и неспецифични защитни механизми на организма. Кантактуването с плътна повърхност предизвиква участието на комплекс от бактериални ензими, които катализират образуването на полизахариди, повишаващи колонизацията и защитата. Структурата на биофилма е такава, че имунните отговори се насочват само към тези антигени, открити на външната повърхност на биофилма, антитела и друг серум или протеини, неуспели да проникнат в биофилма. Фагоцитите не могат ефективно да погълнат бактериално натрупване в матрикса от полизахариди, прикрепен към плътна основа. Това причинява образуването от фагоцитите на голямо количество про-възпалителни ензими и цитокини, водещо до възпаление и деструкция на близките тькани.

Когато се коментира честотата на хроничните заболявания и инфекции, причинени от биофилми, не бива да се забравя, че все пак това, което ни е познато, е само връх на айсберга. Изследванията категорично доказват, че имунокомпрометираните индивиди по-лесно стават терен за развитието на биофилм от патогени, причиняващи хронифициране на възпалителни заболявания, чрез въздействие върху имунния статус, с които организмът не може са се справи сам.

\section{Изследване}

Изследването на биофилма обичайно е било спъвано от невъзможността да се изследва биофилмът цял, неразрушен, в триизмерен план. Трудно е или е невъзможно да се оцени генната експресия и метаболизма на единичен микроб вътре в биофилма. Обаче с напредването на лазерните и дигиталните технологии, сканиращата електронна микроскопия и новите флуоресцентни сонди , изследователите вече могат да си изградят триизмерен модел на биофилма и да локализират в него специфичната генна експресия.

При използването на сканираща лазерна микроскопия на биопсичен материал от налични биофилми в човешкия организъм морфологично се диференцират Haemophilus influenzae, Streptococcus pneumoniae и Moraxella catarrhalis. C други mexники и методи на изследване като сканираша електронна микроскопия, транслигавична електронна микроскопия, хистобиохимични и микробиологични тестове е доказано и наличието на Staphylococcus aureus, Pseudomonas aeruginosa $u$ Echerichia coli.

\section{Заключение}

Това запознаване с микробиалните биофилми има за цел да представи механизмите на формирането и развитието им, както и на стратегии за предпазване и лечение на свързаните с тях заболявания. Биофилмите представят нова концепция за поддържането и на хронични резистентни на лечение с антибиотици инфекции на ушите, носа и гърлото $(3,5)$. Продукцията и отделянето на ендотоксин, увеличеното съпротивление към имунната система на организма и снабдяването с резистентни микроорганизми е същността на биофилма, който може да сложи началото на инфекциозен процес. Ролята на биофилмите при хронифициране на възпалителните заболяванията на ушите, носа и гърлото за пръв път се доказва при средните отити. Наличието на бактериален биофилм в лигавицата на средното ухо при деца се доказва не само при секреторен отит (OME), но и при често повтарящите се отити. Биофилми са доказани и при аденоидите на деца с хронични риносинуити $(10,14,15)$. Те играят важна роля и при хроничните тонзилити. 
Директното доказване на наличието на биофилми чрез биопсиране на лигавицата на средното ухо при деца с OME и рецидивиращи отити подкрепя хипотезата за връзката между биофилмите и хроничните заболявания на средното ухо и определя тези заболявания като биофилм свързани. В оториноларингологията често срещани заболявания като хроничен тонзилит, хронични синуити, ОМЕ и холестеатом отговарят на клиничните критерии за биофилм асоциирани, неподатливи на лечение заболявания, неефективно лекувани дълготрайно с антибиотици $(1,3,5,8,9)$. УНГ-хирурзите често поставят импланти във вентилирани зони като трахея, средното ухо, околоносните кухини, всички податливи към прикрепването на биофилми $(6$, $11,14,15)$.

Хроничните инфекции са по-лесно разбираеми когато се разглеждат в светлината на биофилмите. Съществуването на бактериите в биофилм е в основата на заболявания като хроничните средни отити, хроничните тонзилити, хронични риносинуити, холестеатом и инфекции и на други органи и системи.

\section{Литература:}

1. Psaltis AJ, Ha KR, Beule AG, Tan LW, Wormald PJ. Confocal scanning laser microscopy evidence of biofilms in patients with chronic rhinosinusitis. Laryngoscope 2007, Jul., 117(7): 1302-6.

2. Hardie KR, Heurlier K. Establishing bacterial communitics by ,word of mouth": Lux 5 and autoinducer 2 in biofilm development Nat. Rev. Microbiol., 2008, Jun., 9.

3. Post IC, Hiller NL, Nistico L, Stoodley P, Ehrlich GD. The role of biofilms in otolaryngologic infections: update 2007 Curr. Opin.otolaryngol Head Neck Surg., 2007, Oct., 15(5): 347-51.

4. Ha KR, Plastis AJ, Tan L, Wormald PJ. A sheep model for the study of boifilms in rhinosinuitis Am. J. Rhinol., 2007, May-Jun., 21(3): 339-45.

5. Vlastarakos PV, Nikolopoulos TP, Maragondakis P, Tragaroulakis A, Ferekidis E. Biofilms in ear, nose and throat infections: hou important are they ? Laryngoscope, 2007, Apr., 117(4): 668-73.

6. Jang $\mathrm{CH}$, Cho JB, Choi CH. Structural features of tympanostomytube biofilmmformation in ciprofloxacin resistant Pseudomonas otorrhea Jnt. J. Pediatr. Otorhinolaryngol., 2007, Apr., 71(4): 591-5.

7. Sanclement JA, Webster P, Thomas J, Ramadan HH. Bacterial biofilms in surgical specimens in patients with chronic rhinosinusitis Laryngoscope, 2005, Apr., 15(4): 578-82.

8. Sanderson AR, Lied JG, Hunsaker D .Bacterial biofilm on the sinus mucosa of human subjects with chronic rhinosinuitis Laryngoscope, 2006, 116(7): 1121-26.
Разглеждането на хроничните бактериални инфекции, свързани с имплантирани материи като причина и последица за развитието на бактериални биофилми, налага промяна в лечебните тактики и използваните медикаменти. Сигурен път за решаването на выпроса с наличната биофилм инфекция при неуспех от лечението с други средства е отстраняването на инфектираното устройство.

Друг алтернативен начин за контрол върху биофилмите е възможността да се повлияе върху целостта и устойчивостта на структурата на биофилма чрез разрушаване на матрикса, блокиране на процесите на изграждане и нарастване, прекъсване на комуникациите вътре в общността. Продължават изследванията върху микробиалния биофилм с цел подобряване на диагностичните възможности, предотвратяване и лечение на свързаните с биофилми инфекциозни заболявания, като в международните екипи за тези проучвания участват микробиолози, имунолози, биохимици, клиницисти, патолози, биоинженери и се прилагат образни технологии и математически модели.

9. Psaltis AJ, Weitzel EK, Ha KR, Wormald PJ. The effect of bacterial biofilms on post-sinus surgical outcomes. Am J Rhinol., 2008, Jan-Feb; 22(1): 1-6.

10. Zuliani G, Carron M, Gurrola J, Coleman C, Haupert M, Berk R, Coticchia J. Identification of adenoid biofilms in chronic rhinosinusitis. Arch Otolaryngol Head Neck Surg., 2007, Aug., 133(8): 843; author reply 843.

11. Ramadan HH, Sanclement JA, Thomas JG. Chronic rhinosinusitis and biofilms. Otolaryngol Head Neck Surg,, 2005 Mar., 132(3): 414-7.

12. Stewart P, Costerton J. „Antibiotic resistance of bacteria in biofilms“. Lancet, 2001, 358 (9276): 135-8.

13. Bendouah Z, Barbeau J, Hamad W, Desrosiers M. „Biofilm formation by Staphylococcus 2006 aureus and Pseudomonas aeruginosa is associated with an unfavorable evolution after surgery for chronic sinusitis and nasal polyposis“. Otolaryngology-head and neck surgery 2006, 134 (6): 991-6.

14. Marev. D. Chronic Otitis Media with Effusion Sequelae in Children Treated with Tubes. „Pro Otology“, Vol. 4,1, p. 54-56, 2004.

15. Marev. D. Behavior and Developmental Effects of Otitis Media with Effusion in the Teens. "Pro Otology“, Vol. 4, 2-3, p. 110-112, 2004. 